\title{
CYCLOPHOSPHAMIDE EFFECT ON COCCIDIOIDOMYCOSIS IN THE RAT
}

Mirta C. REMESAR, Jorgelina L. BLEJER, Ricardo NEGRONI \& Marta R. NEJAMKIS

\begin{abstract}
SUMMARY
Coccidioidomycosis is a systemic mycosis, endemic in arid areas of the American continent.

The rat was employed as an experimental host, since it had been shown to reproduce human lesions and present a chronic course of disease with granulomas mainly restricted to lungs.

Given the influence of immunosuppressive therapy on the clinical course of human coccidioidomycosis, we studied the effect of cyclophosphamide (CY) in the experimental rat model. Accordingly, animals were inoculated with 400 Coccidioides immitis arthroconidia of the Acosta strain, by intracardiacal route. As single $C Y$ doses failed to alter the course of disease, three schedules were used: A) 4 daily doses of $20 \mathrm{mg} / \mathrm{kg}$ each, prior to C. immitis inoculation; B) 4 similar daily doses after infection; and $\mathrm{C} ; ; 6$ doses of $20 \mathrm{mg} / \mathrm{kg}$ each, given from day +1 to +4 , then on days +8 and +9 , post infection (pi), taking day 0 as the time of fungal inoculation. The first two schedules inhibited antibody formation up to day $28 \mathrm{pi}$, without modifying cellular response to coccidioidin as measured by foodpad swelling. Initially, there was greater fungal spread than in controls receiving $\mathbf{C}$. immitis alone, which proved self limiting in the latter. In contrast. schedule $\mathrm{C}$ led to $55 \%$ mortality, with both humoral and cellular response abrogation, accompanied by extensive $\mathbf{C}$. immitis dissemination. Histology disclosed significant alterations, such as the persistence of primary infection sporangia, corresponding to the acute stage of coccidioidomycosis in the absence of granuloma development.

Therefore, the observed depression in cellular immunity seems responsible for the lack of inflammatory reaction capable of restricting sporangia proliferation in tissues which, in turn, enhances pathogen spread and mortality rate.
\end{abstract}

KEY WORDS: Cyclophosphamide; Coccidioidomycosis; Immunosuppression.

\section{INTRODUCTION}

Coccidioidomycosis is a systemic mycosis which is endemic to arid areas in the American continent $t^{6}$. It is acquired by inhalation of conta minated soil, affecting both man and several ani mal species ${ }^{2.8 .15}$
Asymptomatic or subclinical infection pre sents a high incidence among endemic area dwell ers but is mostly self-limited, although many individuals exhibit latent coccidioidomycosis foci in lung parenchyma and hilar lymph nodes ${ }^{8}$

Departamento de Microbiologia, Facultad de Medicina. Buenos Aires. Argentina

Address for correspondence: Dr. M C. Remesar. Departamento de Microbiologia. Facultad de Medicina -. UBA Paraguay 2155. Piso 12, 1121 Buenos Aires. Argentina 
REMESAR. M. C.: BLEJER.J. L.: NEGRONI, R. \& NEJAMKIS, M. R. - Cyclophosphamide effect on coccidioidomycosis in the rat. Rev. Inst. Med. trop. S. Paulo, 31(6): 423429,1989

10. 17. Patent cell-mediated immune response has been shown essential to circumscribe infection ${ }^{21}$ 22

Rodents are particularly susceptible both to natural and experimental infection ${ }^{16}$. In fact, we have already shown ${ }^{16}$ that rats regularly develop widespread coccidioidomycotic lesions in lungs, liver, spleen and thymus, following intracardiac (ic) inoculation, with the appearance of granu lomas limited to the lungs in the chronic stage.

The multifunctional alkylating agent cyclophosphamide (CY) has been extensively employed in experimental trials to modulate the host's immune response and often exacerbates latent infections.

Since immunosuppresive treatment is known to modify the clinical course of human coccidioidomycosis ${ }^{7.12 .}{ }^{23}$, here we attempted to determine the effect of suitable doses and ade quate schedules of $\mathrm{CY}$ in the $\mathbf{C}$. immitis-rat mo del.

Both humoral and cellular immune respon se, histopathological alterations and organ colo ny-forming unit ( $\mathrm{CFU}$ ) count served to evaluate the degree of immunosuppression.

\section{MATERIAL AND METHODS}

\section{Animals}

Buffalo/Sim inbred adult male rats raised in our bioterium were used. For each separate experiment, 3.4 month-old animals weighing 200-250 g were employed.

\section{Microorganism}

Coccidioides immitis (Acosta strain), was originally obtained from a patient. Cultures were maintained in Sabouraud's honey agar medium at $28^{\circ} \mathrm{C}$ and repeatedly passaged in rats at the Centre of Mycology Faculty of Medicine, Buenos Aires University,

\section{Inoculation procedure}

Arthroconidia were harvested in saline from well sporulated cultures and counted in a hemocytometer. Each rat received 400 arthrospores by intracardiacal route (ic) suspended in $0.1 \mathrm{ml}$ of isotonic saline solution.

\section{Tests performed}

Animals were killed at days $7,14,21$ and 28 post-infection (pi). At least 3 rats were used for each experimental point to determine: 1) viable $\mathbf{C}$. immitis CFU count in tissue, 2 ) serum antibody formation, 3 ) footpad swelling increase and 4 ) organ histopathological alterations.

\section{1 -- Viable $C$. immitis CFU count in tissue}

Lungs were removed aseptically and their weight determined. Organs were separately pla ced in glass homogenizers containing a suitable volume of sterile saline. Each homogenized or gan was serially diluted in saline and $0.1 \mathrm{ml}$ seed ed on a Sabouraud's honey Petri dish. After 3-4 days incubation at $37^{\circ} \mathrm{C}, \mathrm{CFU}$ s were counted and their number expressed as $\log _{10} \mathrm{CFU}$ per gram of organ. Two weeks later these colonies were microscopically controlled searching for the presence of typical arthroconidia.

\section{2 - Serology}

Assays were performed by agar gel immuno diffusion and by Counter-Immuno-Electropho resis (CIE) in gel medium supplemented with Polyethyleneglycol 6000 , as described elsewhe$\mathrm{re}^{24}$. Briefly, gel for immunodiffusion was prepared with $1 \%$ Difco Noble Agar in phosphate buffer pH 7.2 plus $1 \%$ Polyethyleneglycol 6000 . For CIE, $0.9 \%$ agarose in veronal buffer $\mathrm{pH} 8.2$, sup plemented as above was employed.

\section{3 - Footpad Swelling test}

Skin tests were carried out by inoculating $0.1 \mathrm{ml}$ of coccidioidin, prepared as described elsewhere ${ }^{20}$, containing $2 \mathrm{mg} / \mathrm{ml}$ of protein, in the hind footpad, and the same volume of sterile saline in the contralateral footpad.

Thickness was measured 24 h later by means of an Oditest precision caliber and percentage swelling calculated as below.

$$
\text { Swelling }=\frac{\text { Thick. inoc. footpad Thick control footpad }}{\text { Thick control footpad }} \times 100
$$


REMESAR. M, C.: BLEJER, J. L.: NEGRONI, R. \& NEJAMKIS. M. R. - Cyclophosphamide effect on coccidioidomycosis in the rat. Rev. Inst. Med. trop. S. Paulo, 31(6): $423429,1989$.

\section{$4-$ Histology}

Lungs, liver and spleen were fixed in $10 \%$ for malaldehyde and paraffin embedded. Parafin sections were stained with hematoxylin and eosin (H \& E).

\section{CY (Endoxan Asta, Labinca SA) schedules}

The drug was dissolved in sterile distilled water and injected by intraperitoneal route (ip) in daily serial doses of $20 \mathrm{mg} / \mathrm{kg}$ body weight for each inoculum. Three administration sche dules were employed:

Schedule A: 4 doses (total dosage $80 \mathrm{mg} / \mathrm{kg}$ ) at days $-8,-6,-4$ and -1 , taking 0 as $\mathbf{C}$. immitis infection day:

Schedule B: 4 doses (total dosage $80 \mathrm{mg} / \mathrm{kg}$ ) at days $1,2,3$ and 4 days post-infection (pi);

Schedule C: 6 doses (total dosage $120 \mathrm{mg}$ kg) at days $1,2,3$ and 4 , then at 8 and 9 days pi. A 3-day (5-7 days pi) resting period was adopted to avoid drug toxicity to the highly CY-sensitive Buffalo rat.

For each animal group receiving one of the above $\mathrm{CY}$ schedules, a C. immitis-infected group receiving sterile saline alone according to sche dules $\mathrm{A}, \mathrm{B}$ and $\mathrm{C}$ served as controls.

The efficacy of CY schedules was tested by contact hypersensitivity. A 5\% 2,4-dinitrofluoro benzene (DNFB) dose was given at day 0 (sensitization timel on the rats' shaven flank, triggering the reaction at day 7 on the pinna with $0.3 \%$ DNFB. Ear thickness vs contralateral pinna thickness was measured $24 \mathrm{~h}$ later. Mean values for schedules $A$ and $B$ were $0.129(n=6)$ and 0.177 (n $=7$ ) respectively, vs $0.695(\mathrm{n}=6)$ for a non-sup pressed control group ( $\mathrm{p}<0.001$ in every case).

All CY schedules patently abrogated DNFB contact hypersensitivity and were assayed to de termine which one, if any, was capable of signifi cantly modifying the course of disease, as shown by mortality, lung CFU count, footpad swelling test, antibody formation and histological alterations

\section{RESULTS}

\section{Mortality percentage}

No mortality was recorded for animals infec ted with $400 \mathrm{C}$. immitis arthrospores, nor for tho se receiving $\mathrm{CY}$ schedules $\mathrm{A}$ or $\mathrm{B}$. Rats treated by schedule $\mathrm{C}(120 \mathrm{mg} \mathrm{CY} / \mathrm{kg}$ ) were found to exhi bit $55 \%$ mortality from 14 to 17 days pi.

\section{C. immitis CFU count}

Lung samples harvested at various times pi showed a significant increase in CFU count among $\mathbf{C Y}$-treated animals.

For schedules $\mathrm{A}$ and $\mathrm{B}$, values peaked at day 14 pi. later approaching levels for non-sup pressed rats (Fig. 1).

In contrast, $\mathrm{CY}$ schedule $\mathrm{C}$ showed the grea test colony count up to 28 days pi, together with gross and microscopical evidence of $\mathbf{C}$. immitis proliferation in spleen, liver and kidney.

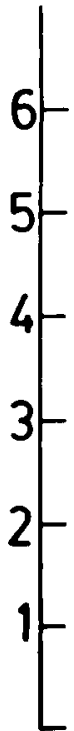

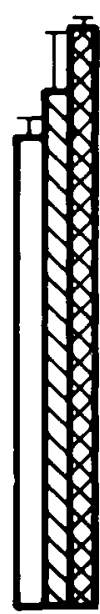

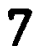

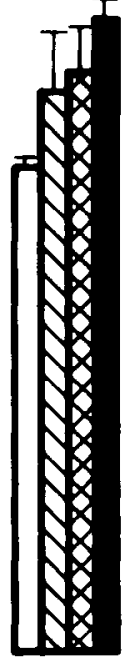

14

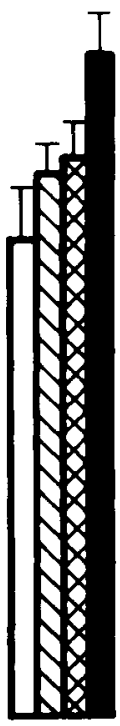

21

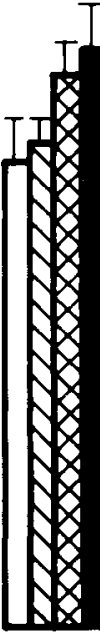

28
Fig. 1 - CFU lung count in Coccidioides immitis infected adult male rats treated with 3 different $C Y$ schedules (see Mate rial and Methods, or left untreated: a) at 7 days pi; b/ at 14 days pi; c) at 21 days pi: and d) at 28 days pi. White bars results from infected untreated control rats: striped bars, sche dule A; doubly striped bars, schedule B; and black bars, sche dule $\mathrm{C}$

Values in abscissae represent days pi; in ordinates, $\log _{1}$ C immitis CFU:g lung. 
REMESAR, M. C.: BLEJER,J. L.; NEGR ONI, R. \& NEJAMKIS, M. R. - Cyclophosphamide effect on coceidioidomycosis in the rat. Rev. Inst. Med. trop. S. Paulo, 31(6): 423429,1989

\section{Footpad swelling test}

Footpad measurements were made $24 \mathrm{~h}$ af ter coccidioidin footpad inoculation. Values at day 7 pi for all 3 schedules were disregarded due to minimal swelling even in controls. There were no significant differences between animals receiving schedules $\mathrm{A}$ or $\mathrm{B}$ and infected untreated controls. However, in rats receiving schedule C, swelling barely reached $5 \%$ at 14 days pi with a slight increase at days 21 and $28 \mathrm{pi}$, when infec ted untreated control levels exceeded $40 \%$ (Fig. 2 ).

\section{Serum antibody (Ab) determination}

Ab production became positive in controls by day $21 \mathrm{pi}$, but in schedules $\mathrm{A}$ and $\mathrm{B}$ was only detectable at 28 pi. In schedule $C$, it remained undetectable at all evaluation times.

\section{Histopathology}

C. immitis infected control animals exhibi ted two types of inflammatory response. Up to 7 days pi, the reaction featured leucocytes with numerous polymorphonuclear cells together with larger sporangia spherules having thin walls and numerous small endospores iprimary infectious sporangia $)^{15}$. As from day $14 \mathrm{pi}$, follicu lar giant cell granuloma formation became evi dent. accompanied by a decrease in sporangia number, whose size was smaller and walls thick

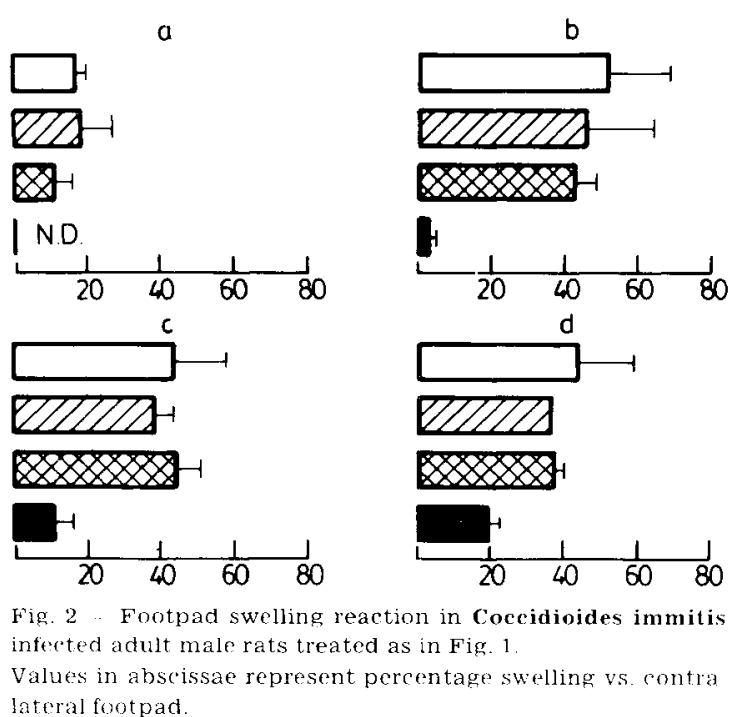

er and which harboured larger but less numerous endospores (cystic sporangia) ${ }^{15}$ (Fig. 3 ). Lung was more commonly affected though on occasion granulomas without C. immitis were observed in liver.

CY treatment by both schedule $A$ and $B$ led to contrasting alterations vs controls, mainly: a) no follicular giant cell granuloma formation was observed up to day 21 pi: b) primary infec tious sporangia only became cystic at day 21 pi (Fig. 4); and c) there was greater spread to liver and spleen.

Findings proved much more severe follo wing schedule $\mathbf{C}$ (Fig. 5 a \& 5 b): a) instead of granulomas, hemorrhagic suppurative necrotic areas were widespread in lung: b) primary infec tious sporangia persisted throughout; and $c$ l specific lesions with typical sporangia were de tected in liver and spleen and often in kidney.

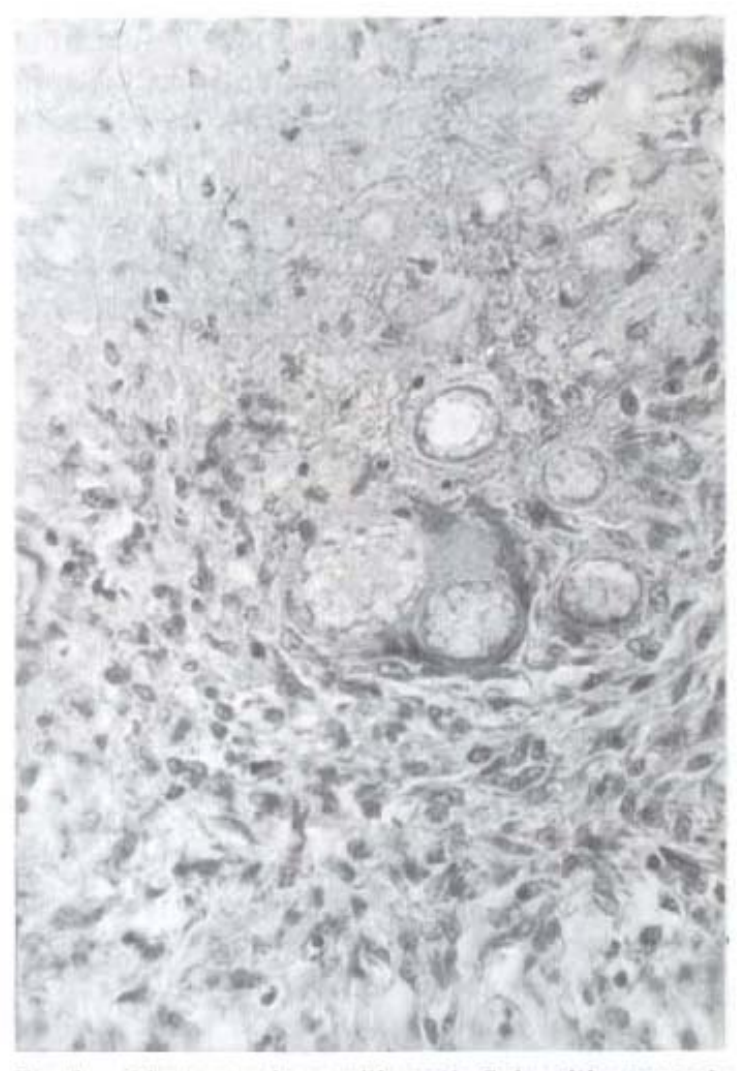

Fig. 3 - Giant granuloma with cystic C. immitis sporangia in CX untreated rat lung. $\mathrm{H} \& \mathrm{E} 250 \mathrm{X}$ 
REMESAR, M. C.; BLEJER. J. L.: NEGRONI. R. \& NEJAMKIS, M. R. -- Cyclophosphamide effect on coccidioidomycosis in the rat. Rev. Inst. Med. trop. S. Paulo, 31(6): 423429.1989

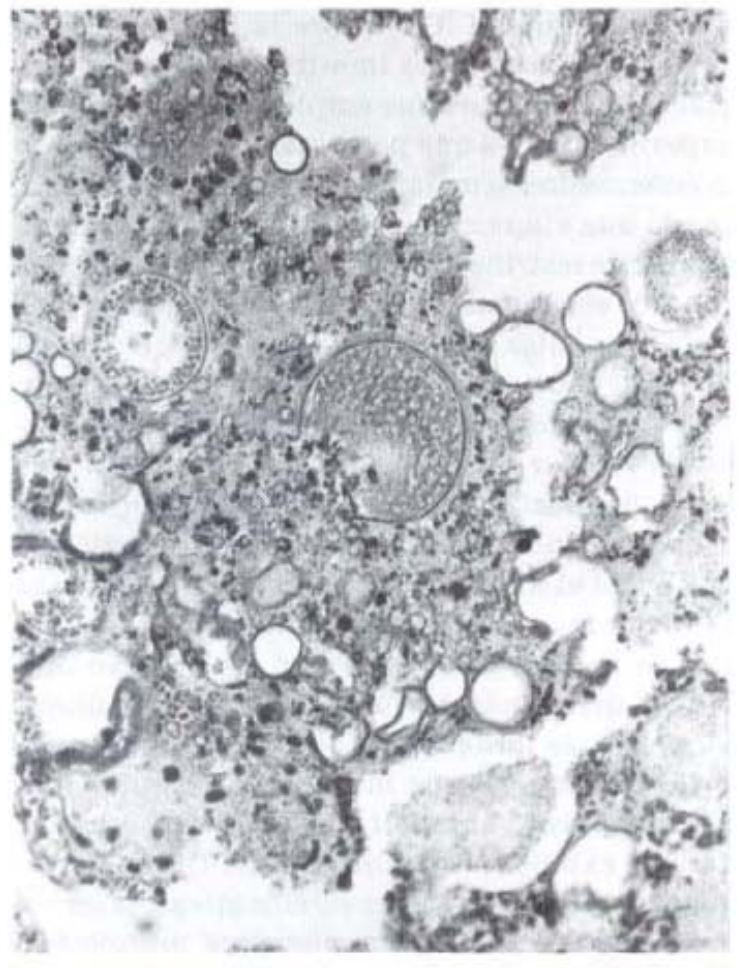

Fig. 4 - Lung inflammation showing primary infectious C. immitis sporangi and a few cystic sporangia, but without gra nulomas, in a CY-treated rat iSchedule A or B, see Materials \& Methods: H \& E $250 \mathrm{X}$

\section{DISCUSSION}

Human coccidioidomycosis infection is mainly asymptomatic or subclinical and reaches a high incidence among inhabitants of endemic areas.

Therefore, a satisfactory experimental model is essential to explain its infective mecha nism. Previous work ${ }^{15}$ has shown that the ic inoculated rat faithfully reproduces histological lesions found in man, with the development of widespread infection coursing chronically with granulomas mostly restricted to lung.

The exacerbation of infectious diseases due to immunosuppression, whether by drugs or ra. diation, has been amply studied ${ }^{1,3.11}$. Thus, irradiated mice ${ }^{4}$ become more susceptible to $\mathbf{C}$. immitis infection due to an impairment of cellular or $\mathrm{T}$-dependent immunity.

Here we employed CY as immunosuppressive drug and found that a single dose failed to
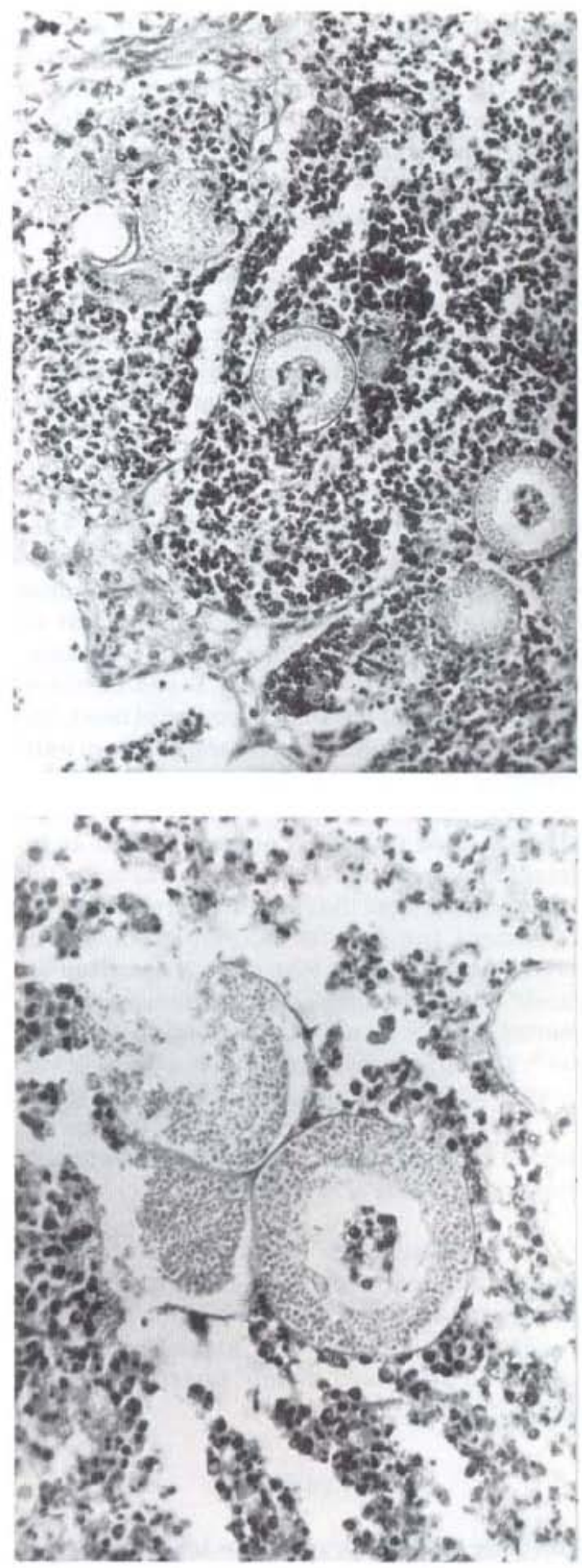

Fig. 5 - a) Necrotic suppurative hemorrhagic lung areas with primary infectious $\mathrm{C}$. immitis sporangta in a CY treated rat (Schedule C. see Materials \& Methods) H \& E 250 X. b) Same as above, at higher magnification. 
REMESAR. M. C.: BLEJER, J, L : NEGRONI.R.\& NEJAMKIS. M. R. - Cyclophosphamide effect on coccidioidomycosis in the rat. Rev. Inst. Med, trop. S. Paulo, 31(6): 423429.1989.

modify the course of disease (data not shown). Since previous work with this host had required serial $\mathrm{CY}$ doses to alter the development of a viral infection ${ }^{13}$, we applied similar schedules to the $\mathbf{C}$. immitis-rat model, after confirming that such treatment was capable of abrogating DNFB contact hypersensitivity.

There was no mortality among $\mathbf{C}$. immitis inoculated rats receiving $\mathrm{CY}$ doses up to $80 \mathrm{mg}$. $\mathrm{kg}$. In contrast, $120 \mathrm{mg} / \mathrm{kg} \mathrm{CY}$ in 6 doses with a 3 -day resting period to avoid drug toxicity ${ }^{1: 1}$ induced overt illness and $55 \%$ mortality at day $14 \mathrm{pi}$

As regards humoral immunity, an $80 \mathrm{mg} \mathrm{kg}$ $\mathrm{CY}$ dose proved sufficient to abrogate response up to 21 days pi, since antibodies only became detectable at 28 days pi. On raising the dose to $120 \mathrm{mg} / \mathrm{kg}$, inhibition was maintained at all times tested. These findings were not unexpec ted as $\mathbf{C Y}$ is known to impair $\mathbf{B}$ cell function. without affecting the clinical course of most fun gal diseases. Besides, the protective role of anti bodies against systemic mycosis is little known Although all three schedules led to wider fungal dissemination in several organs, as well as in creased colony count in lung, it was only the $120 \mathrm{mg} \mathrm{kg} \mathrm{CY}$ dose that inhibited granuloma de velopment and specific footpad swelling. Our overall findings agree with reports on histoplas mosis ${ }^{9}$ and candidiasis ${ }^{5}{ }^{14}$ in immunosuppressed murine models as well as on $\mathbf{C}$. immitis in the rat $^{18}$. The appearance of granulomas closely cor related with $\mathrm{T}$ cell mediated immunity: thus their scarcity in rats receiving $\mathrm{CY}$ during the second week pi, seems to correlate well with the impairment of DTH reactions.

In conclusion, the recorded lack of inflam matory response capable of circumscribing tis sue sporange dissemination leading to subse quent fungal spread and higher mortality should be attributed mainly to cellular immu nity inhibition.

\section{RESUMEN}

Efecto de la ciclofosfamida en la infección por Coccidioides immitis en la rata

E1 propósito de este trabajo fue estudiar el efecto de la inmunosupresión causada por la dro ga ciclofosfamida (CY) sobre la infección de la rata con Coccidioides immitis por via intracar díaca. Este huésped fue empleado como modelo experimental, ya que presenta una evolución de la enfermedad semejante a la del hombre, alcan zando una etapa crónica con granulomas principalmente restringidos a los pulmones. Se utiliza ron tres esquemas de CY: A / 4 dosis de $20 \mathrm{mg} / \mathrm{kg}$ cada una, antes de la inoculación de Ci; B/ 4 dosis de igual cantidad de CY, luego de la infección: y C) 6 dosis de $20 \mathrm{mg} / \mathrm{kg}$ cada una, administradas desde el día +1 hasta +4 y continuando los dias +8 y +9 post-infección (pi). Los dos primeros esquemas inhibieron la formación de anticuer pos hasta el día $28 \mathrm{pi}$, sin modificar la respuesta celular a la coccidioidina, medida como hincha zón de la almohadilla plantar. Se observó una mayor diseminación fúngica inicial, autolimitándose más tarde. Por el contrário, el esquema $\mathrm{C}$ provocó un $55 \%$ de mortalidad, disminución de la respuesta humoral y celular, acompañada de una extensa diseminación del Ci. La histo logia mostró alteraciones significativas, tales como persistencia de esporangios de primoinfec ción, correspondientes al estadío agudo de la coccidioidomicosis, con ausencia de desarrollo de granulomas. Por lo tanto, la depresión observada en la respuesta celular debido al tratamien to con $\mathrm{CY}$ sería la responsable de la ausencia de la reacción inflamatoria capaz de restringir la proliferación de esporangios en los tejidos, 10 cual a su vez favorece la diseminación del $\mathrm{mi}$. croorganismo patógeno y el aumento de morta lidad.

\section{ACKNOWLEDGMENTS}

This work was supported by grants provided by the National Research Council (CONICET, Argentina) and by the University of Buenos Ai res.

\section{REFERENCES}

1. ADLER, B. \& FAINE, S. - Susceptibility of mice treated with cyclophosphamide to lethal infection with Leptos. pira interrogans Serovar pomona. Infect. Immun., 14 $703-708,1976$.

2. AJELLO, L, - Coccidiodomycosis. In: PROCEEDINGS OF SECOND COCCIDIODOMYCOSIS SYMPOSIUM. TUC son. Arizona, The University of Arizona Press. 1967

3. BEAMAN, B. L. \& MASLAN. S. - Effect uf cyclophos. phamide on experimental Nocardia asteroides infection in mice. Infect. Immun., 16: 995 1004, 1977 
REMESAR. M. C.: BLEJER.J. L.: NEGRONI. R. \& NEJAMKIS. M. R. - Cyclophosphamide effect on coccidioidomycosis in the rat. Rev. Inst. Med. trop. S. Paulo, 31(6): 423429.1989.

4. BEAMAN, B. L. PAPPAGIANIS. D. \& BENJAMINI, E - Significance of $T$ cells in resistance to experimental murine coccidioidomycosis. In fect. Immun., 17: 580 ऽ85. 1977

5. BISTONI, F: BACCARINI, M: BLASI, E: MARCONI, P.: PUCCETTI, P. \& GARACI. E. - Correlation between in vivo and in vitro studies of modulation of resistance to experimental Candida albicans infection by cyclophos phamide in mice. Infect. Immun., 40: 46 55, 1983

6. BORELLI, D. -- Prevalence of systemic mycosis in Latin America. In: INTERNATIONAL SYMPOSIUM ON MY COSIS. Washington. 1970. PROCEEDINGS. Washington. Pan American Health Organization. 1970. p. 2838 iScien tific Publication N. 205i.

7. CALHOUN, D. L: GALGIANI, J N : ZUKOSKI, Ch. \& COPELAND, J. G. - Coccidiodomycosis in recent renal or cardiac transplant recipients. In: EINSTEIN, H. E. \& CANTANZARO. A. - Coccidioidomycosis. International Conference on Coccidioidomycosis. 4:. Washington. 1985 PROCEEDINGS p. $312-318$

8. CONAT, N. F.: SMITH, D. T.: BAKER, R. D. \& CALLA WAY, J. L - MANUAL OF CLINICAL MYCOLOGY. 3rd. ed. Philadelphia. W. B. Saunders Company, 1971. p. $134-169$.

9. COZAD. G. C \& LINDSEY, T. S. - Effect of cyclopho. phamide on Histoplasma capsulatum infections in mice Infect. Immun., 9: 261265,197

10. EMMONS. C. W.: BINFORD. C. H. \& UTZ. J. P. - Cocci dioidomycosis. In: EMMONS. C. W.: BINFORD. C. H. \& UTZ, J. P. - Medical mycology. 2nd. ed. Philadelphia. Lea \& Febiger, 1970. p. 207.229.

11. GRAyBiLI, J.R. \& MiTCHELL, L. - Cyclophosphamido effects on murine cryptococcosis. Infect. Immun., 21: 674677.1978

12 HENDEL, E E HUI A N DIAZ, J \& BOYLEN C T - Pneumocystis carinii pneumonia and malignant lym phoma in a homoscxual male with disseminated coccidioi domycosis. In: EINSTEIN. H. E. \& CATANZARO. A.Coccidioidomycosis. International Conference on Cocci dioidomycosis. 4., Washington. 1985. Proceedings. p 305-311.

13. LASCANO, E. F . BLEJER. J. L. : GALASSI. N. V. \& NE JAMKIS M. R - Brain inflammatory exudate in Junin Virus infected rats: its characterization by the immunope roxidase (PAP) technique. J. Neuroimmunol, 11: 105.116 1986
14. MOSER. S. A \& DOMER, J. E. - Effects of cyejophos phamide on murine candidiasis. Infect. Immun.. : 376386,1980

15. NEGRONI. P.-- Coccidiodomicosis. In: NEGRONI. P - Las blastomicosis y coccidiodomicosis. Micosis profundas y viscerales. Buenos Aires. Comision de Investi gación Clínica, 1966. v. 3. p. 235354

16. NEGRONI, R.: FINQUELIEVICH, J. L. \& ELIAS COSTA M. R. I. - Estudio de la coccidioidomicosis experimental en ratas Wistar. Rev. argent. Micol., 8: 7 11, 1985

17. RUBINSTEIN. P. \& NEGRONI.R - Coccidioidomicosis In: RUBINSTEIN, P. \& NEGRONI. R. - Micosis bronco. pulmonares del adulto $\mathbf{y}$ del niño. 2: ed. Buenos Aires. Ed. Beta. 1981, p. 291323

18. RUBINSTEIN, H. R.: MASIH, D. T.: MARTICORENA B. \& RIERA. C. M. - Experimental coccidioidomycosis effects of cyclophosphamide in immunologic responses. Mycopathologia (Den Haag), 94: 9195.1986

19. SHARBAUGH, R. J. \& GROGAN, J. B - Suppression of reticuloendothelial function in the rat with cyclophos phamide. J. Bact. 100: 117 122, 1969

20. STANDARD. P. G. \& KAUFMAN. L. - Immunologieal procedure for the rapid and specific identification of Coc cidioides immitis eultures. J. clin. Microbiol., 5: 149153. 1977.

21. STEVENS D. A : PAPPAGIANIS. D.: MARINCOVICH V. \& WADDER. T. F. - Immunotherapy in recurrent roc cidioidomycosis. Cell. Immunol., 12:37 48. 1974

22. STEVENS. D. A. - Coccidioidomycosis. New York. Ple num Plublishing Corporations. 1980

23. STEVENS. D. A. - Clinical manifestations and manage ment of coccidioidomycosis in the compromised patient. In: WARNOCK, D. W \& RICHARDSON. M. D. - Fungal infection in the compromised patient. New York. J. Wiley \& Sons, 1982. p. 199-20

24. ZAROR L : ROBLES A. M. \& NEGRONI. R - Prucbas de inmunodifusion en medios gelosados con agregado de polietilenglicol 6000 para el serodiagnóstico de las micosis. Rev. argent. Microbiol., 10:61-64, 1978

Recebido para publicaçâo em 2511989 